\title{
Business Ethics: A View From The Classroom
}

Diane D. Galbraith, Slippery Rock University, USA Fred L. Webb, Slippery Rock University, USA

\begin{abstract}
The global economy has been devastated in the last year and according to Federal Reserve Chairman, Ben Bernanke, America's economy was threatened, reminiscent of the Great Depression. Our nation is also in a serious ethical and moral decline, as evidenced by steroid use in baseball, corporate scandals, accounting fraud, religious immorality within churches, human trafficking and the rise of cheating and plagiarism in our school systems. The lines between right and wrong have been blurred, relegating moral and ethical boundaries to outdated standards. This paper will seek to establish some answers regarding university students in the classroom such as, what is the perceived attitudes of today's college students toward ethical behavior, are they naïve, etc? Also, this paper will explore ways in which professors can reinforce appropriate ethical behavior as an essential element in our society.
\end{abstract}

Keywords: Ethics, morality, business ethics, values, and millennial students

The Need for Ethics

"The unexamined life is not worth living." (Socrates)

\section{INTRODUCTION}

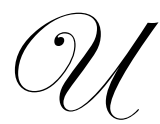

niversity students as future leaders may need more soft skills like empathy, self-knowledge and sound judgment, blended with technical and quantitative skills. Aristotle, the great philosopher (384-322 BC), explored some of these core issues as they pertained to a person's character and the characteristics for an individual human being to become a good person. 'Ethos' is the Greek word for custom or habit, the characteristic conduct of an individual human life. Beginning with Aristotle, ethics is the study of human conduct, and the Stoics held that all behavior - for good or evil — arises from the ethos of the individual (Peters, 1967). The ethical perspective from a business view point represents challenges of working in the new economy with a code of moral standards that set standards of conduct (Schermerhorn, 2006). Hopefully, a business person's distinguishing features or attributes can be identified through his/her character and reputation by exhibiting moral and ethical strength. It is what you really are in your heart.

The notable philosopher Aristotle's belief was that happiness and living well should be the ultimate aim of human life, but the acquisition of material items and the satisfaction of desires are less important than the achievement of virtue. Moderation between reason and desires can lead to true happiness, attained through a cultivation of virtues that is consummated in a life worth living. Further defined, virtues are characteristics to act in certain ways in situations and for the formulation of habits of behaving in certain ways. Ethics is then a practical discipline that is exemplified through good conduct from habits that have been learned through repeated action and correction. Aristotle noted, "We are what we repeatedly do." As such, moral and ethical excellence is a result of repetitious training in good habits.

We study ethics or 'what is right or wrong', to improve our lives. Good action as expressed by Socrates and Plato is tantamount to a well-lived life. Stanford Encyclopedia of Philosophy (2003) states that Aristotle believed that human beings must acquire through proper upbringing and habits, the ability to see, on each occasion which 
course of action is best supported by reasons. Practical wisdom is acquired through deliberative emotional and social skills, not just learning general rules.

So, how did we go so far astray? Maybe the moral and ethical environment in which we live is more invisible than our physical environment.

This surrounding climate contains the ideas of how to live. It determines what we find acceptable or unacceptable, admirable or contemptible...It determined our conception of when things are going well and when they are going badly; what is due to us and what is due from us, as we relate to others. It shapes our emotional responses, what is a cause of pride or shame, anger or gratitude, or what can and cannot be forgiven. It gives us our standards (Blackburn, 2003, p.1). This environment shapes our very identities as described by G.W.F. Hegel, (1770-1831).

\section{SIGN OF THE TIME: ONE ROOT CAUSE OF UNETHICAL BUSINESS BEHAVIOR}

If we briefly analyze American history from the beginning of the $20^{\text {th }}$ century to the present, there have been remarkable changes in technological advancements, industrialization, and communications. America has passed through the invention of electricity, telephones, automobiles, and airplanes in the 1900's to advanced electrical power generation, wireless telephones, hybrid automobiles and space travel by the beginning of the $21^{\text {st }}$ century, all within a very short space of time. America became the leading industrialized nation in the world coming out of World War II with a positive balance of payments (favorable balance of trade with the world). This continued through the 1950's, 1960's and until the early 1970's. American businesses produced and sold without much thought of globalization impacting their competitive world position until the output began to decline. American business came out of World War II with an attitude or sense of invulnerability. A major portion of our competitors were bombed during the war, eliminating global competitors (Gingrich,1995). The attitude of superiority set in at the peak of the business cycle that led to the severe performance expectations for American business in the 1970's and continued into the 1980's and 1990's. This era has been labeled the decade(s) of greed (Lauer, 2003).) These competitive performance pressures appeared to be unrealistic, but in reality, was the result of a lack of strategic

planning in previous years. Meeting these competitive challenges could only in the eyes of some businesses, be achieved by cutting corners or acting in an unethical manner (Hill, 2009). America entered the age of "unfavorable balance of trade" which continues today. Pressures upon management to correct business performance became so great that short term and unethical decisions were made in an effort to re-generate the business cycle toward continued growth.

In business management we have a basic principle known as "The Loose - Tight Principle" (Snyder, Dowd \& Houghton, 1994). When management issues become somewhat out of control, it is management's responsibility to tighten the reins through policies and procedures and bring the issues back into control. The corollary is when issues are managed so tightly that is stifles creativity and performance then it is time to review policies and procedures and loosen the reins to provide management the ability to plan, organize, lead and control at peak performance. A good example is management's organizational process of "Centralization" and "Decentralization" of decision-making within the business organization (Schermerhorn, 2006). The age of globalization has created a revitalized need by American top business managers to develop and work the plan and lead their business organizations by setting the examples for ethical behavior. If the business leaders are not acting ethically, other employees may not act ethically (Hill, 2009). It is past time for American businesses to tighten their "Codes of Conduct" and manage ethical behavior. Businesses have a life cycle of their own as depicted in Figure 1.

\section{Ethical Lapses}

Management researchers began to study business ethics during the 1960's and interest in this arena has continued to grow for the last 40+ years 9 (Trevino \& Nelson, 2004). Although there are a myriad of examples of ethical lapses in business from Enron, WorldCom, Adelphia Cable, and Lehman Brothers to Bernie Madoff, every institution in our society has been tarnished. From sex scandals in the White House, to Olympic judging, groups such as religious, education, philanthropic and sports institutions have not avoided ethical or moral violations. Although, a greed factor has been detected in many organizations, a focus on positive, ethical behavior resulting in socially responsible institutions is more the norm. Many organizations have ethics committees, ethics officers, codes of moral and ethical conduct, training programs, etc. 


\section{THEORICAL BUSINESS LIFE CYCLE}

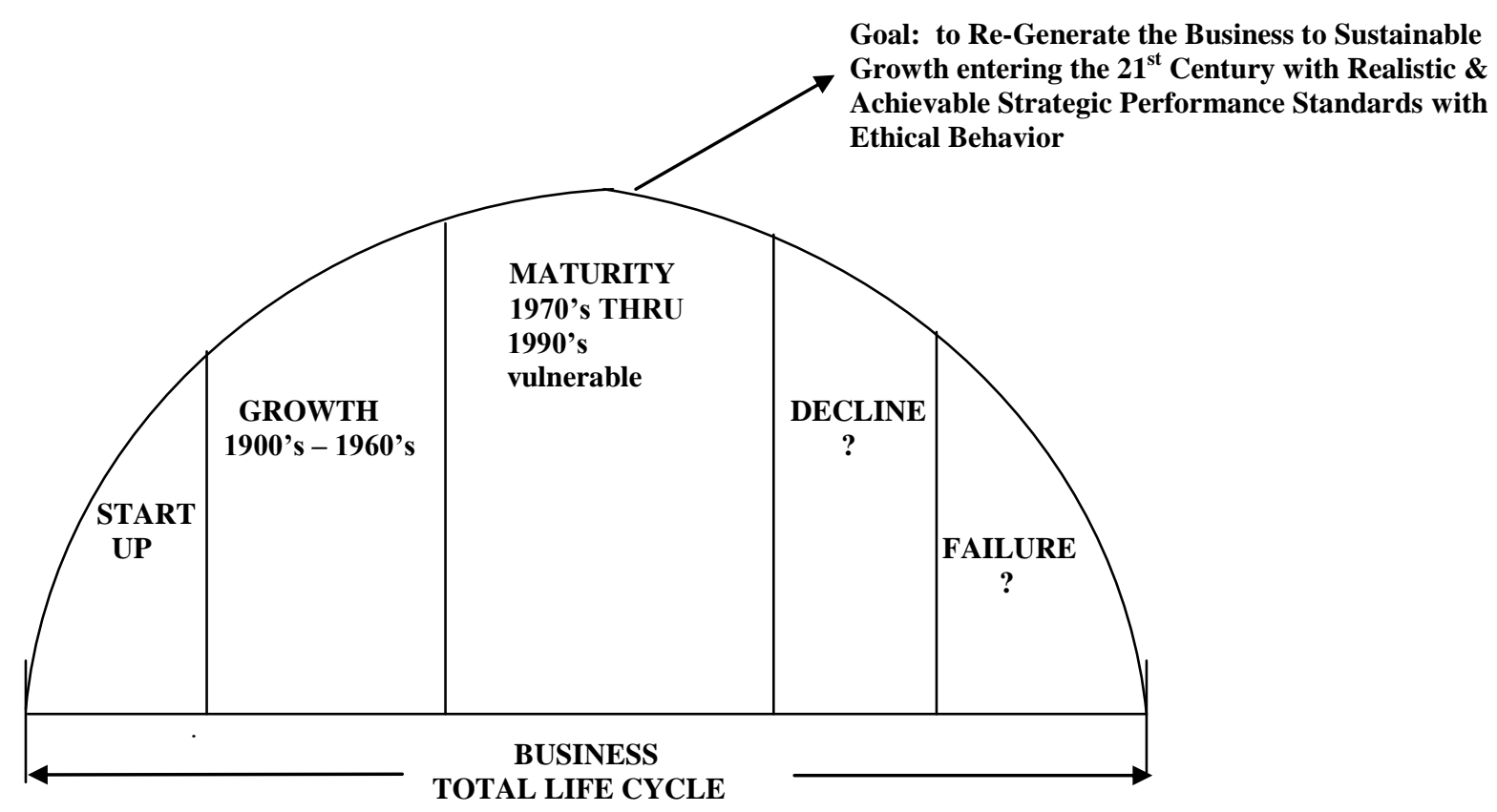

Figure 1: A Theoretical Business Life Cycle. This figure represents a theoretical life cycle model for a business. Business life cycles are similar to product life cycles in marketing. The point is that businesses have a life with cycles measured in time along the horizontal axis. Continuous growth is the goal and can be measured by a variety of quantifiable factors on the vertical axis.

\section{Ethical Myths}

So how do you guide people into making the right choices and to behave accordingly? Let's start by dispelling some of the myths of business ethics. A number of myths, by Carter McNamara (1997-2008) are displayed below in Figure 2:

Myth 1: Business ethics is more a matter of religion than management.

Truth - Managing values and conflict among employees is the goal of business ethics.

Myth 2: Our employees are ethical so we don't need attention to business ethics.

Truth - Although most individuals know the Golden Rule, when faced with complex challenges, many uncover the "gray areas".

Myth 3: Business ethics is a discipline best led by philosophers, academics and theologians.

Truth - Beyond the philosophy, business ethics is a management discipline with practical application.

Myth 4: Business ethics is superfluous -- it only asserts the obvious: "do good!"

Truth - The value of a code of ethics is specific to that organization and its employees.

Myth 5: Ethics can't be managed. Ethics are always managed, albeit indirectly at times.

Truth - Strategic priorities such as profit maximization, cost containment, etc. can influence morality.

Figure 2: Ethical Myths and Dispelling Values 


\section{Bad Apple Syndrome}

Many believe that ethics cannot be taught beyond the age of 10 and Lester Thurow, former Dean at MIT's Sloan Management School of Management stated that business schools could do little if students have not already learned ethics from their families, clergy, other schools or employers (Trevino \& Nelson, 2004, p. 8). This presupposes that the 'bad apples' cause and engage in the unethical behavior that spoil the environment for the majority and that they cannot change or be rehabilitated. This paper disagrees with this premise, as the authors believe that most people would "like to do the right thing" and therefore, ethical education is valuable. Moral judgment has been proven to continue to develop through adulthood and moral reasoning is a lifelong process.

Psychologist Lawrence Kohlberg has attempted to provide a framework for moral education through his Theory of Moral Development created from the time of his doctoral dissertation to the publication of the Standard Issue Scoring Manual in 1987. Kohlberg hoped that his stages could provide a framework for moral education. These stages are described below in Figure 3:

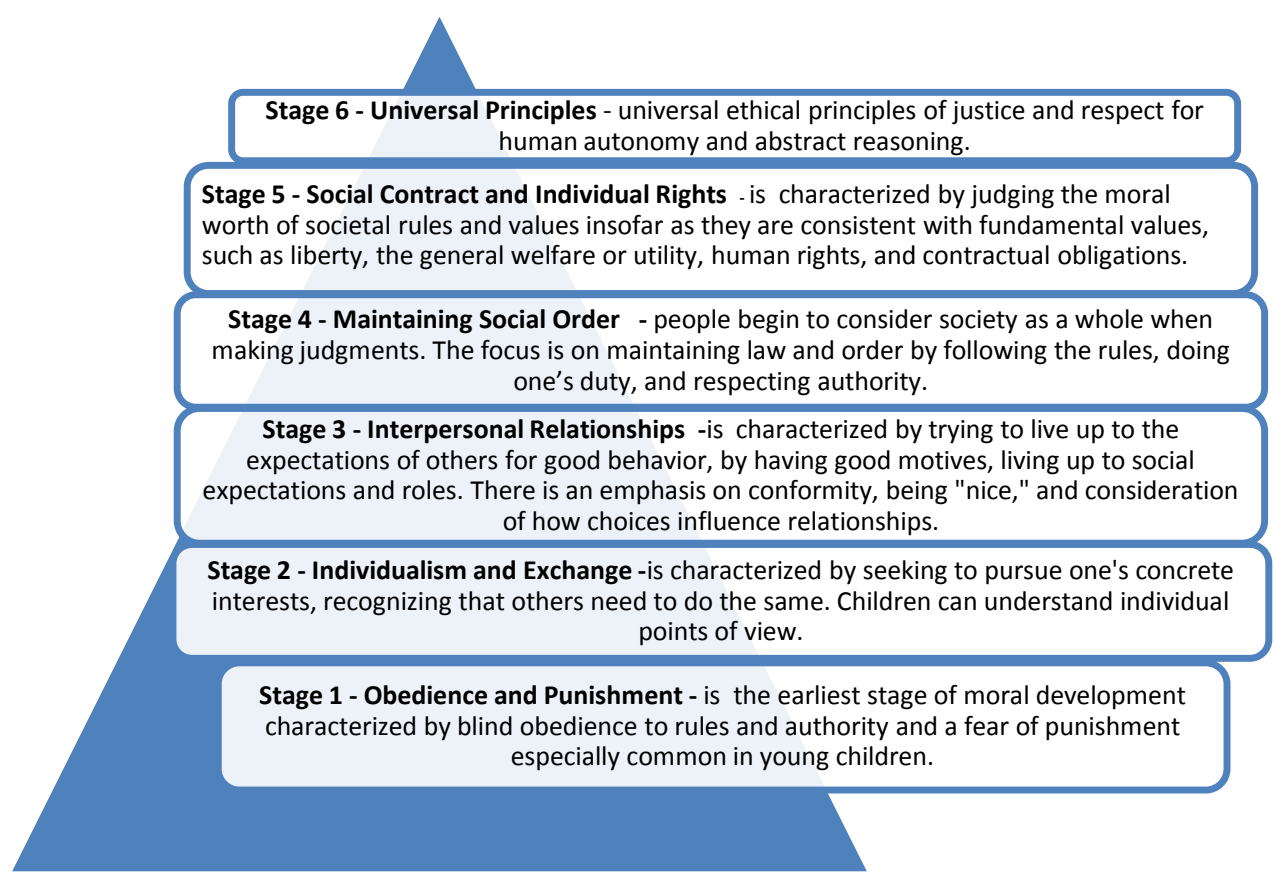

Figure 3: (Van Wagner, 2009), (Lerner, 1997) and (http://education.stateuniversity.com/pages/2150/Kohlberg-Lawrence1927-1987.html\#ixzz0Lw9XrSSt)

Not everyone reaches Level 6, according to Kohlberg. At stages, 5 and 6 people are more concerned with the principles and values that make for a good society. At stage 5, they emphasize basic rights and the democratic processes that give everyone a say, and at stage 6, they define the principles by which agreement will be most just (Crain, 1985).

A stage 7 was also hypothesized by Kohlberg, to complete the journey for students, that includes dealing with some of the ultimate questions of suffering and death answered through a faith component that allows the individual to move from despair to a oneness with the nature of God (Kohlberg, 1981, p.351). If he is correct, this would provide students with a strong motivation to move beyond the $6^{\text {th }}$ stage.

Character is the basis of ethical behavior is 'what you do when no one is watching' and is developed over time through the accumulation of values gained from a variety of sources including families, friends, schools, coaches, and churches. These influences should be reflected in ethical decision-making and be relatively stable. 
People are not always guided by an internal moral compass; rather many look to external sources for direction. Organizations that reward profitable decisions over the well-being of people perpetuate unethical environments. Sometimes, apples are spoiled by organizations that condone and even expect unethical behavior (Trevino \& Nelson, 2004). Good character then, is not enough to prepare students for ethical challenges that they will face in the workforce.

\section{Millennial Students}

The millennial students born approximately between 1980 and 2001 bring a different perspective to the classroom and the workplace. In general, according to Ron Alsop (2008), author of The Trophy Kids Grow Up, these individuals are technology savvy, intolerant of ambiguity, are uncomfortable with risk and independent decision-making, civic-minded, have high self-esteem, close parental ties, high expectations and they want a work/life balance. The future requires leaders who are competent, caring and value-based. In a brief 20 question survey on personal values, the author queried 50 college students, 26 males and 24 females, aged $19-24$ and two others aged 29 on their respective values. The model used was The Study of Values; (Alsop, 2008). Each question had 6 possible responses and the results were charted in Figure 4, in 6 different categories as follows:

1. Theoretical - primary interest is the discovery of truth. In the laboratory, field, and library and in personal affairs, the purpose is to know the truth above all else the major concern of such a person is to order and systematize knowledge and to understand the meaning of life.

2. Economic - The economic person is interested in what is useful. Based originally on the satisfaction of bodily needs and self-preservation, the interest has shifted to the practical affairs of the business world such as the production and marketing of goods and the accumulation of wealth.

3. Aesthetic - This person finds satisfaction in form, harmony and beauty. Life is regarded as a procession of events with each impression to be enjoyed for its own sake, tending toward individualism and idealism.

4. Social - The highest value for this person is love rather than power. Humanistic by nature, the social person is helpful, unselfish and kind.

5. Political - This person is interested in power, influence and status. Their values are social influence and the exercise of authority.

6. Religious - The highest value of this person is peace, spiritually. These people see something divine in every event; they experience meaning in the affirmation of life and participation therein.

Figure 4: Categories - The Study of Values (Alsop, 2008)

The results of this millennial group of university students was the economic value scored the highest among the males and the females, while the religious scored the lowest among both groups. These individuals agree that the accumulation of wealth is more valuable than a belief in a higher being, peace and self-denial. Culture influences personal values and different organizations promote different values, so mismatches may be stressful for both. Although this tool does not measure morality or negative values such as greed or violence, it does identify basic value systems which normally are fairly well-established and unlikely to change at these ages.

\section{Teaching Ethical Wisdom for Changing Times in the Business Profession}

Being professors of business management with many years of business experience, we are aware of the need for exposing our students to the practices of good ethical behavior. University students can live with two conflicting sets of rules or behaviors...the same can hold true with business people. Why is this possible? Some would surmise that it is the result of peer pressures, environmental pressures, and overall temptations to act or respond to a given situation or go along with the crowd. To follow and hold to ethical practices a person needs a unified set of ethical values resulting in ethical behaviors that can resist compromising when faced with ethical dilemmas. As it was pointed out previously, character is the basis of ethical behavior and is developed over time by 
exposure to families, friends, schools, coaches and churches. We would hope these influences would be positive for good moral and ethical development. Assuming they were positive, the person enters the business profession with a stable and unified set of values prepared to act ethically because it is the right thing to do...not because it pays financially or it is more important to go along with the peer or management group (Rae and Wong, 2004). Therefore, we must teach the students there could be contrasting tensions and challenges in business that will test their value system. They may be tested to compromise their ethical standards to achieve financial success. So the question: Are you the same person at home/church and at work in the business profession as displayed in Figure 5? It may require a strong mental conviction to hold fast to positive ethical behaviors when faced with ethical dilemmas.
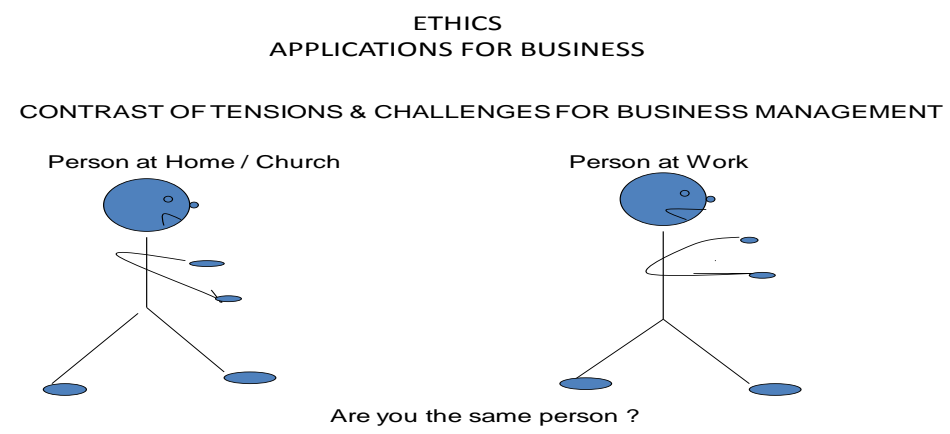

Figure 5: Can you live with the potential of two conflicting sets of rules? "There can be no true peace when things that we believe in are different than the things we do daily" (Finefrock, 2004).

\section{Pedagogy: Opinion Poll of Classroom Attitudes - "A Starter for Engaging Students...What Does it Really Tell Us?"}

From the viewpoint and experiences of the writers, today's university classroom environment is one, for the most part, made up of diverse opinions when it comes to responding to ethical dilemmas given specific business situations. We have attempted to challenge the students to think at a higher level with solid justifications for their solutions to ethical dilemmas. Decisions go beyond a simple right or wrong response. How can you justify your actions? At best, recognizing ethical dilemmas in business and doing nothing, is not an answer.

The objective of this pedagogy, adopted format from Gardenswartz and Rowe, 2003, is to raise the awareness of ethical behaviors in the business environment and provide a means to engage the students in discussions relative to approaches to solving ethical dilemmas. In addition, we discuss the need for role models of change for good practical applications of business ethics. The goal is to raise the students' level of thinking to one who is willing to command sound ethical practices in business... fight for the right approach to ethical dilemmas in business.

The methodology applied is in the form of an opinion poll of twenty questions handed out for the students to quickly respond to the question: "Are you a change agent for ethical behavior?" The poll is anonymous, only identifying gender and age. See Exhibit-A...The results are tabulated on an excel spread sheet, based upon an "Awareness Spectrum." The students do not see the Awareness Spectrum until after responding to the poll. Class discussions are initiated, interpreting the results for each question raising significant issues of what and why the importance of business ethics. Generally more questions than answers at this stage of the process. Business codes of conduct are usually established by the organizational managers but in these classroom discussions it is critical to point out that individual business employees have a significant influence on correcting or establishing ethical practices. The opinion poll provides an opportunity for each student to examine their responses, compare to other replies and establish personal goals for their own growth in becoming commanders for ethical behavior. The students are quizzed on a variety of behaviors in the opinion poll: 
1. Which behaviors do you commonly do? Do least?

2. Which behaviors are the most difficult for you?

3. What hinders you from doing the most difficult ones?

4. Which behaviors are most important to you for become more effective in ethical situations?

5. When, where and how can you begin developing your ability to command ethical behaviors?

A four-point Likert scale is applied representing the awareness spectrum in Figure 6.

\begin{tabular}{|c|c|c|}
\hline & \multicolumn{2}{|c|}{ AWARENESS SPECTRUM } \\
\hline & $\begin{array}{l}\text { NAÏVE } \\
\text { AVOIDER } \\
\text { O-1.9 pts. }\end{array}$ & $\begin{array}{l}\text { NEUTRAL } \\
\text { NO OPINION } \\
2-2.9 \text { pts. }\end{array}$ \\
\hline & $\begin{array}{l}\text { CHANGE } \\
\text { AGENT } \\
\text { 3-3.9pts. }\end{array}$ & $\begin{array}{l}\text { COMMANDER } \\
\text { MORAL CODES }\end{array}$ \\
\hline & \multicolumn{2}{|c|}{$\begin{array}{l}\text { Naïve / Avoider, one who is deficient in worldly wisdom or informed judgment } \\
\text { Neutral / no opinion, one who may not care } \\
\text { Change agent, one who will provide a different course/position/direction } \\
\text { Commander of moral codes, one who will battle for sound ethical practices }\end{array}$} \\
\hline
\end{tabular}

Figure 6

The results of 241 student opinion polls are attached in Exhibit-B and Exhibit-C, representing the summarized questions and the gender comparisons. The results are not real surprising since this opinion poll was taken before classroom lectures and engagements for best practices of ethical business behaviors. It serves much like a pre-test to observe relative attitudes towards ethical behaviors. A post poll or test with different questions might indicate whether or not our goal, of developing habits of thinking that are needed to develop and determine a set of moral principles to which we can reasonably assent, was accomplished. Again, the results of the poll are not conclusive, although interesting...more research beyond this paper would be required to reach serious conclusions. This poll and paper are designed to stimulate discussions about moral development to move beyond simple solutions, or acceptance of the moral standards we may have uncritically absorbed from family, peers, organizations, nation, or culture (Velasquez, 2002).

\section{RESULTS FOR DISCUSSION}

1. Students are not "Naïve or Avoiders" of ethical behavior. All scores were at or above 1.9 on the awareness spectrum...see Exhibit-B. We hopefully expected this since at the age of 22, we would expect them to have informed judgments. The average age was 21.9 years; a birth date of around 1988...typically the Millennial generation.

2. Over-all students are not commanders of ethical behavior. Students do not appear to be strong "Fighters" for ethical behavior. The mean score for all students was 2.7 "Neutral / No Opinion"...see Exhibit-B. This may be the result that some questions may have been confusing for them based on a lack of previous training.

3. This does not mean the same students would not be "Commanders and Fighters" for ethical behavior given specific situations of importance to the business environment. Case studies given specific business situations created discussions that indicated some students would definitely fight for their beliefs for ethical behavior given a situational case re: an ethical dilemma. 
4. The poll results showed a difference between male and female respondents. Males scored higher than females on 19 out of 20 questions. Question \#13 was a tie score and question \#14 was very close. Although both question \#13 and \#14 were not scored greater than neutral or no opinion? When the males scored high, females also scored high, but not as high as males. When the males scored low, the females scored low also, but always lower than the males. This result opens up a new research field in business ethics that is beginning to be studied as female managers are on the rise in business. Carol Gilligan, a psychologist, discusses the aspects of "The Voice of Care" which is not exclusively associated with women in business but can represent an important contrast when dealing with ethical dilemmas (Beauchamp \& Bowie, 2004). Again, this is thought-provoking for the students and the research goes beyond this paper.

5. Specific discussions around each question require a collection and a review of data results which is beyond the scope of this written paper.

Engaging the students in discussing the results of the opinion poll, usually brings about questions and specifics relative to what does it really mean? This is intentional because the discussions can lead into applying their thoughts and reactions to situational cases designed to introduce the classical or foundational approaches to solving ethical dilemmas. We believe that students can be taught good ethical behavior for business applications.

Teaching ethical approaches to ethical dilemmas basically revolves around people having different views of right and wrong... given a particular situation. Most situations have multiple approaches to solving the dilemma given the individual's mind set on value judgments. Business experience has proven that engaging in dialogues with people generally brings out the facts of the situation and hence provides some light on possible approaches to solving the dilemma. There may not be an absolute best approach to the solution depending upon the various ethical attitudes of individuals or the group. Let's look at some examples:

\section{A Situational Case - "The Gold Watch"}

Jack has 29 years and 11 months of employment with his firm and had been an outstanding employee. His wife Beth is seriously ill with cancer and her wish is to relocate to her home 3000 miles away. Jack was preparing for this and had notified his boss, Ed, a year ago that he would retire in approximately one year. Jack's position would not be easy to fill. Jack and Ed worked together in finding a replacement which took more than six months. Jack needed to leave one month early because of the terminal illness of Beth. The retirement party was planned and many were prepared to attend. Ed went to his boss Skip with the requisition for Jack's gold watch. A very expensive gold watch was the standard 30-year retirement gift. Skip explained to Ed the gold watch was not authorized because Jack was short one month of thirty years employment with no vacation time left. What would be the best solution to this dilemma?

\section{A Situational Case - "Leaky Lips"}

You have been assigned to lead up a project team to solve a supplier shortage problem. The industry capacity for this product has been exhausted and assembly plants have been shutting down because of the shortage. In the future several hundred employees will be laid off if the problem is not resolved. Your assignment was to find additional supply.

You were at dinner with a friend at a major restaurant and overheard a conversation that got your attention in a booth close to yours. It was your competitor discussing the same problem. He had news of a supplier located in a remote Canadian location who had a unique process for manufacturing the needed product for both your assembly plants. Your competitor went on to describe the name and location of the potential new supplier. What should you do with this information?

Discussing these situational cases, the students will have engaging dialogues with disagreements, value differences, alternative views and possible group consensus and even group think. After the discussions, it is time to introduce the classical approaches to solving ethical dilemmas, illustrated below in Figure 7. 


\section{The Progression Of Discussions}

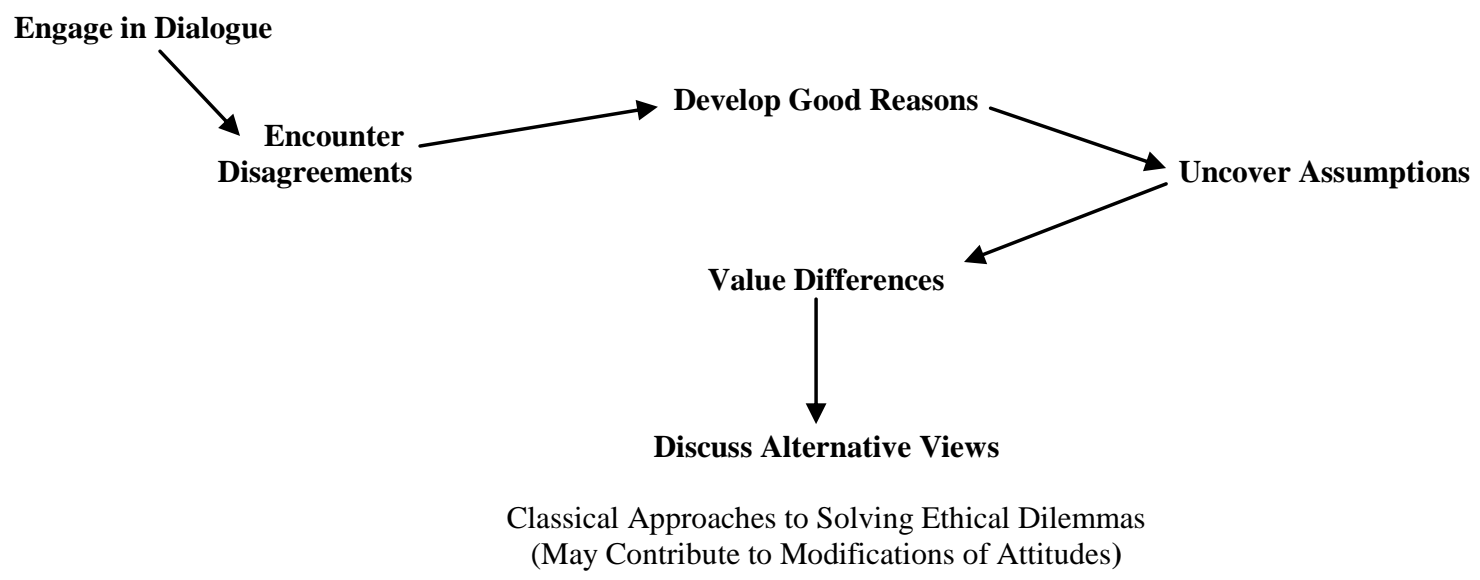

Figure 7: Adopted from Marvin T. Brown's model, 2003

\section{Classical Approaches to Solving Ethical Business Dilemmas}

Often when discussing difficult ethical dilemmas, many points of view are bounced around the classroom. Controversies will arise and may not get resolved because of the personal opinions and beliefs of individual students. Given the situation, the difference between right and wrong may become blurred in the minds of some students. Beauchamp and Bowie (2004) point out students may perceive the classroom as a sort of bulletin board, upon which scores of opinions are tacked. They proceed by saying it would be a mistake to conclude that critical discussions result only in opinion and monologue. Ethical dilemmas can be if not totally partially resolvable in the context of the classroom engagements. Through the facilitations by the teacher and the introduction of the alternative classical approaches to solving ethical dilemmas a consensus position may emerge. The cases should always be examined in terms of alternative strategies and actions. Disagreements will occur but the learning may be the new found higher thought process of the classic approaches spotting the problems and alleviate or deflect them could be as important as the substantive issues of the cases in question (Beauchamp and Bowie, 2004). Classical approaches to solving ethical dilemmas (Rae and Wong, 2004 and Beauchamp and Bowie, 2004):

1. Ethical Egoism: The theory that the morality of an act is determined by one's self-interest.

2. Utilitarianism: The act that produces the greatest good for the greatest number...that produces the greatest balance of good consequences over harmful ones is the one to choose. Sometimes known as "Consequentialism"...overriding emphasis on the consequences of an act.

3. Emotivism: The judgments expressed simply communicate a person's emotions about a subject...thus nothing else can be true or false.

4. Deontological Systems: One's beliefs based upon principles derived from obligations resulting from religious traditions and secular views of the world. A kind of code or set of rules that has been adopted because they are inherently the right thing to do.

5. Virtue Theory: One who follows the virtue theory follows ethics of character not of duty. The emphases would be consistent with the emulation of the character of Christ.

6. Relativism: A theory that asserts that whatever a culture thinks is right or wrong really is right or wrong for the members of that culture. When in Rome do as the Romans do.

7. Justice View: This view holds that ethical decisions should be based upon the belief that people should be treated fairly, equally and impartially.

8. Human Rights View: One's decisions or actions respect and protect the rights and privileges of the individual. 


\section{The Future for Business Ethical Behavior}

Students will make hundreds of choices every day. Most choices have no significant right or wrong attached to them...like what you eat, when you sleep or wake, etc. Students choosing a business career will always face decisions that carry a little more weight with significant right or wrong approaches. We believe our students do not want to do wrong and do not want to cause others to do wrong. Hopefully, as teachers, we can teach them how to discern ethical issues and develop approaches to solving ethical dilemmas.

It is our responsibility as teachers to provide guidance to our future business leaders to make the business future a positive environment... a balance between the future we make vs. the future we take. Avoid corrupt systems by understanding that:

1. People must always be more important than products.

2. Avoid pride in your own programs, plans and successes.

3. Remember that spirituality must never be compromised.

4. People must always be considered above making money.

5. Do what is right, no matter what the cost.

6. Be involved in businesses that provide worthwhile products and services ...not just things that feed the world's unethical desires.

Good values and ethical leadership has enormous benefits by:

- $\quad$ creating greater retention;

- $\quad$ loyalty and cooperation leading to business success;

- $\quad$ value-based leaders earn more respect;

- $\quad$ values create a direct reflection on the company's reputation; and

- $\quad$ enhances stakeholders' sustainability (Schermerhorn, 2006).

Future research will explore some additional gaps in the literature regarding lapses in ethical judgment and solid ways to prepare students for the future workplace. In addition, this study can also be expanded. Equipping students with a moral compass in their career toolbox is a great foundation for personal and professional success in life. From a bottom line perspective and historically, ethical companies have usually fared better economically. The right people with the right character are a company's best asset. The 'need for greed' has proven to be a very shortterm perspective.

\section{AUTHOR INFORMATION}

Diane D. Galbraith is a Business Professor at Slippery Rock University, where I teach Management, Leadership and HRM. I have taught traditional and non-traditional students at both the undergraduate and graduate level for 10 years. My background includes almost 20 years in the business world, most recently as a Director of a Wireless Business Unit and Regional Manager for AT\&T. I have a B.S. in Business Administration with a major in Marketing and Management; a M.S. in Management and HRM; and a doctorate in Administration and Leadership. My research has focused on adult learning, emotional intelligence, ethics and leadership.

Dr. Fred Webb has extensive domestic and international management experiences in line, divisional and corporate staff positions with the General Motors Corporation and Rockwell International Corporation. He has served as a senior level management consultant for small and large businesses both profit and non-profit. During his consulting assignments, Dr. Webb began teaching as a visiting instructor at Slippery Rock University, Grove City College, and Geneva College. Currently, Dr. Webb is teaching full time at Slippery Rock University as an Associate Professor of Business. He holds a B.S. degree in Education, from Ball State University, a Master of Science in Management degree from Massachusetts Institute of Technology and a Doctor of Education from Duquesne University. 


\section{REFERENCES}

1. Allport, G.W., Ewart, V. P., \& Lindzey, G. (1970). A study of values: A scale for measuring the dominant interests in personality, grade 10-adult. ( $3^{\text {rd }}$ Ed.). Boston: Houghton Mifflin.

2. Alsop, R. (2008). The trophy kids grow up: How the millennial generation is shaking up the workplace. San Francisco: Jossey-Bass.

3. Beauchamp, Tom L. and Bowie, Norman E. (2004). Ethical theory and business. Upper Saddle River, NJ:Prentice-Hall.

4. Blackburn, S. (2003). Ethics: A very short introduction. Oxford, England: Oxford University Press.

5. Brown, Marvin T. (2003). The ethical process: An approach to disagreements and Controversial Issues, $\left(3^{\text {rd }}\right.$. Ed.). Upper Saddle River, NJ: Prentice-Hall.

6. Colby, A., \& Kohlberg, L. (1987). The measurement of moral judgment: Standard issue scoring manual. Volume 2, Cambridge University Press.

7. Crain, W. C. (1985). Theories of development. Upper Saddle River, NJ: Prentice-Hall.

8. Finefrock, M. (2004). The learning project. Retrieved November 10, 2009 From: http://www.thelearningproject.com/resources.html

9. Gardenswartz, L. and Rowe, A. (2003). How much of A diversity change agent are you? Retrieved November 11, 2009 from: http://www.gardenswartzrowe.com/diversity.doc.

10. Gingrich, N. (1995). To renew America. New York: Harper-Collins Publishers, Inc.

11. Hill, C. W. L. (2009). Global business today (6 ${ }^{\text {th }}$ Ed.). New York: McGraw-Hill.

12. Kohlberg, L. (1981). The philosophy of moral development: Moral stages and the idea of justice. Harper \& Row.

13. Lerner, R. M. (1997). Concepts and theories of human development. Mahwah, NJ: Lawrence Erlbaum Associates.

14. McNamara, C. (1997-2008). Complete guide to ethics management: An ethics toolkit for managers. Retrieved September 14, 2009 from: www.managementhelp.org/ethics/ethxgde.htm.

15. (n/a) Lawrence Kohlberg (1927-1987) - Stages of moral development, moral education. Retrieved July 21, 2009 from: http://education.stateuniversity.com/pages/2150/Kohlberg-Lawrence-19271987.html \#ixzz0Lw9XrSSt Peters, F. E. (1967). Greek philosophical terms: A historical lexicon. New York: University Press.

16. (n.d.) Lauer, Matt (2003). As co-anchor on N.B.C. today show. Coined the phrase: Decade of greed. Aired on TV in 1993.

17. Peters, F. E. (1967). Greek philosophical terms: A historical lexicon. New York: University Press.

18. Rae, S. B. and Wong, K. (2003). Beyond integrity: A judeo-christian approach to business ethics. Grand Rapids, MI: Zondervan Publishing. Schermerhorn, J. R. (2006). Management, ( $8^{\text {th }}$ Ed.). Hoboken, NJ: John Wiley.

19. Snyder, N. H., Dowd, J. J. Jr., and Houghton, D. Morse (1994). Vision, values and courage: Leadership for quality management. New York: The Free Press, Simon and Schuster, Inc.

20. Trevino, L.K., and Nelson, K.A. (2004). Managing business ethics: Straight talk about how to do it right. $\left(3^{\text {rd }}\right.$ Ed.). Hoboken, NJ: John Wiley \& Sons.

21. Van Wagner, K, (nd). Kohlberg's theory of moral development. Retrieved July 21, 2009 from: http://pyschology.about.com/od/developmental psychology/a/kohlberg.htm.

22. Velasquez, M. G. Business ethics: Concepts and cases, (5 ${ }^{\text {th }}$. Ed.). Upper Saddle River, NJ: Prentice-Hall.

23. Zalta, E.N. (2003). Stanford encyclopedia of philosophy. Retrieved August 30, 2009 from: http://plato.stanford.edu. 


\section{EXHIBIT A}

\section{ARE YOU A CHANGE AGENT FOR ETHICAL BEHAVIOR?}

How often do I as an individual...

1. Challenge others privately when they make decisions that are clearly NOT ethical?

2. Think about the impact of my comments and actions before I speak or act?

3. Tell the truth even when it hurts?

4. Look at problems logically, impartially and attempting to be objective, fair and making the decision according to some standard that is higher than any specific individual's interest, including my own?

5. Do the right thing, treat others as you would like to be treated?

6. Avoid lying, cheating and acting unethically out of the concern for being caught and punished?

7. Concern myself with lying, cheating, and being immoral and unethical?

8. In my dealings with others, be truthful, trustworthy, honest, open, candid and considerate?

9. Value integrity act with integrity in line with form and spirit of laws, regulations and policies?

10. Risk my values and ethical behavior the same whether at home, church or at work?

11. Practice solving ethical dilemmas with the utilitarian approach, the most good for the most people?

12. Practice solving ethical dilemmas with the relative approach, when in Rome do as the Romans do?

13. Solve or make ethical decisions based upon my emotions at the time?

14. Make ethical decisions based upon my spiritual convictions?

15. Place self-interest in solving ethical dilemmas since it is not a concern?

16. Practice solving ethical dilemmas based upon my personal belief system?

17. Tell a lie to protect someone's feelings from being hurt?

18. Practice being just and fair without sympathy and feelings of others?

19. Never steal something of little value from someone or the organization for no good reasons?

20. Support organizational policies regarding ethical behavior by confronting people who violate those policies, and reporting them if necessary?

\section{Circle: ...Male...Female---Age}

$\begin{array}{cccr}\mathbf{1} & \mathbf{2} & \mathbf{3} & \mathbf{4} \\ \text { Rarely } & \text { At Times } & \text { Usually } & \text { Alway } \\ 1 & 2 & 3 & 4 \\ 1 & 2 & 3 & 4 \\ 1 & 2 & 3 & 4\end{array}$

$\begin{array}{llll}1 & 2 & 3 & 4 \\ 1 & 2 & 3 & 4\end{array}$

$\begin{array}{llll}1 & 2 & 3 & 4 \\ 1 & 2 & 3 & 4\end{array}$

1

2

3

4

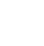

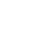

1

$\begin{array}{llll}1 & 2 & 3 & 4 \\ 1 & 2 & 3 & 4 \\ 1 & 2 & 3 & 4 \\ 1 & 2 & 3 & 4 \\ 1 & 2 & 3 & 4 \\ 1 & 2 & 3 & 4 \\ 1 & 2 & 3 & 4 \\ 1 & 2 & 3 & 4 \\ 1 & 2 & 3 & 4\end{array}$




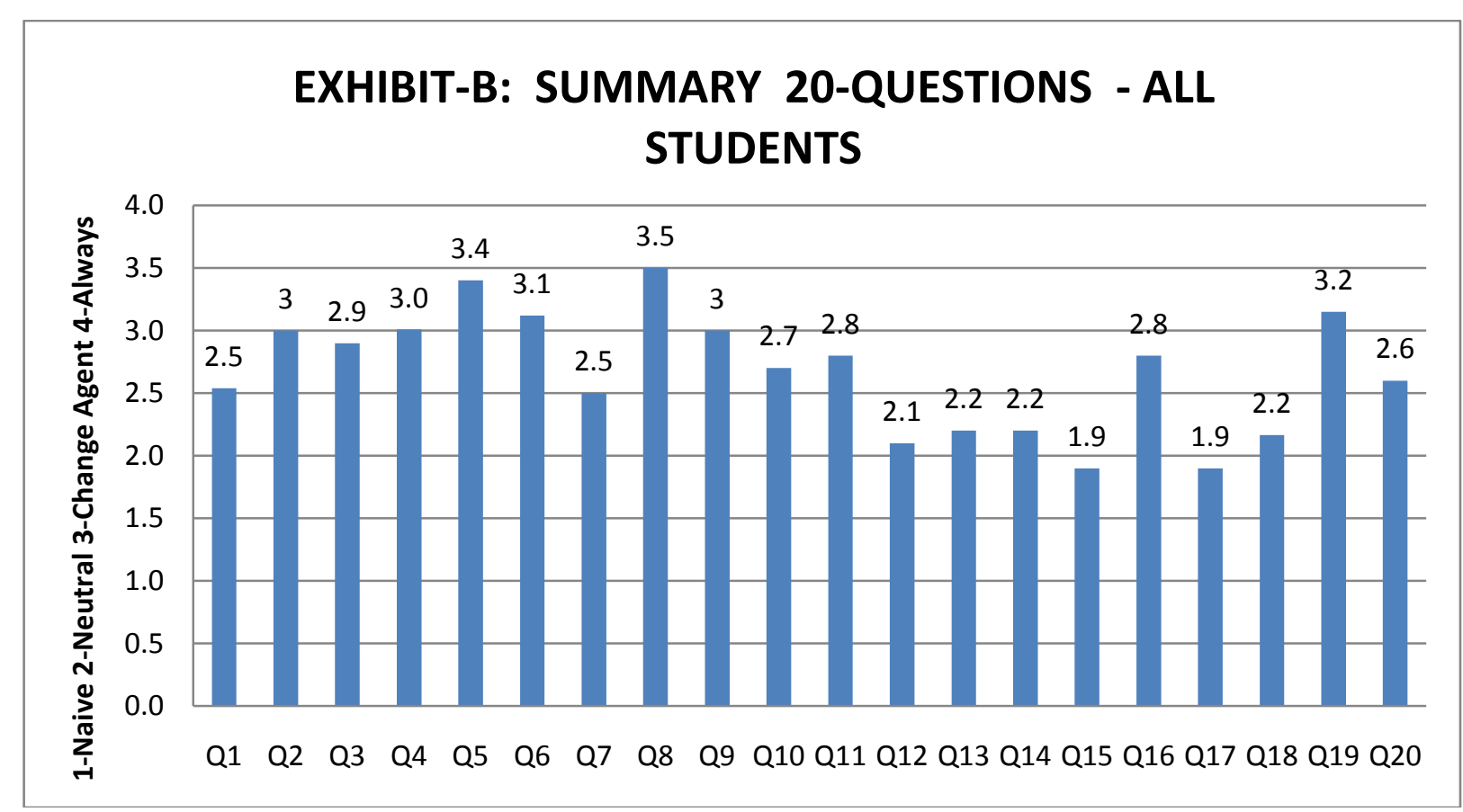

4-Point Likert Scale: (1) Rarely (2) At Times (3) Usually (4) Always

Average Total for all Students and all Questions resulted in a combined score of 2.7.

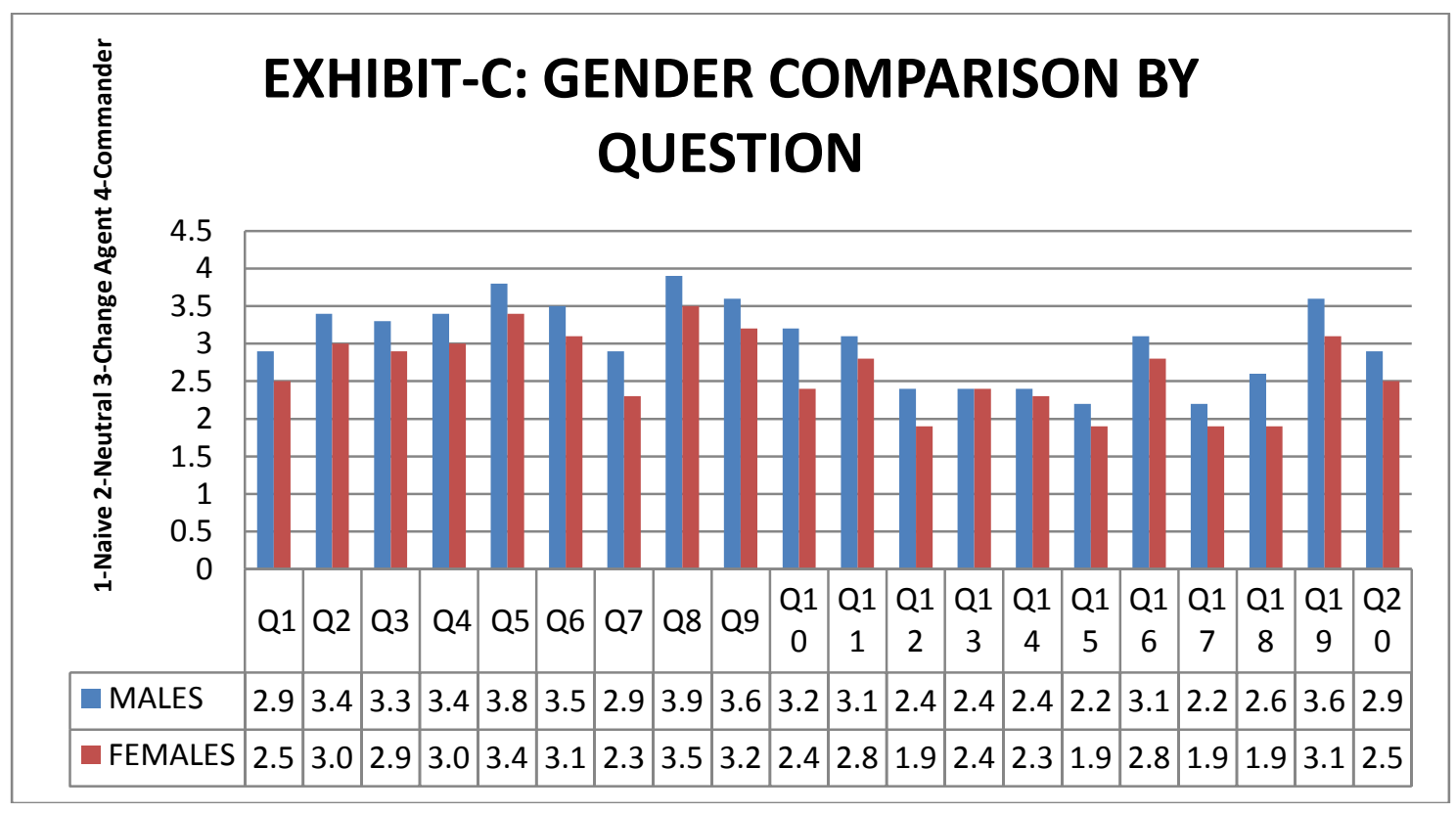

4-Point Likert Scale: (1) Rarely (2) At Times (3) Usually (4) Always 
NOTES 